\title{
Overview: neurobiology of OB protein (leptin)
}

\author{
L. Arthur Campfield* and Françoise J. Smith \\ Department of Metabolic Diseases, Hoffmann-La Roche Inc., Nutley, NJ 07110, USA
}

\begin{abstract}
The rapid elucidation of the properties, target tissues and actions of OB protein, which is the product of the $o b$ gene, has invigorated and energized obesity research as no other finding in this field has in the last 35 years. The circulating concentrations of $\mathrm{OB}$ protein are proportional to adiposity and increase with increasing levels of body fat (Considine et al. 1996). The OB protein pathway is the long-sought hormonal signal pathway from adipose tissue to the brain that plays a critical role in the regulation of energy balance (Kennedy, 1953; Campfield et al. 1996a, 1997a). OB protein is a $16 \mathrm{kDa}$ polypeptide hormone that is secreted from adipose tissue, circulates in the blood, bound to a family of binding proteins, enters the brain, binds to its receptor in hypothalamic nuclei and other brain areas and acts on central neural networks. Available evidence suggests that $\mathrm{OB}$ protein appears to play a major role in the control of body fat stores through co-ordinated regulation of feeding behaviour, metabolism, neuroendocrine responses, autonomic nervous system and body energy balance in rodents, primates and man (Campfield et al. 1996a, 1997a).
\end{abstract}

The mechanisms in the brain responsible for determining the level at which body fat content is regulated in man and other animals are not completely understood. A similar lack of knowledge exists for the mechanisms regulating the neuroendocrine rhythms supporting the adaptation to starvation and reproductive function in man and other animals. Elucidation of the $\mathrm{OB}$ protein pathway within the brain has begun to provide important insights into these, and possibly other, mechanisms. If $\mathrm{OB}$ protein proves to be a useful tool to illuminate the mechanisms controlling body fat content and its corresponding decision rules or algorithms, it may provide the basis for a clearer understanding of the regulation of body fat content and energy balance (Campfield et al. 1996a, 1997a). When these mechanisms are understood at the molecular level, they should provide new targets for therapeutic interventions that will reduce and maintain body fat at reduced levels and, therefore, increase metabolic fitness, reduce risk factors and promote improved health of obese individuals. It is this hope that creates much of the excitement that greets each research advance in the understanding of the OB protein pathway (Campfield et al. 1996a, 1997a).

Since the cloning of the $o b$ gene in December 1994 (Zhang et al. 1994), research has progressed along four parallel paths: (1) regulation of $o b$ gene expression in adipose tissue in mice, rats and man; (2) characterization of the biological actions and definition of the elements of the $\mathrm{OB}$ protein pathway in lean and obese mice and rats; (3) studies of the biology of OB protein in lean and obese human subjects; (4) studies of the brain structures and mechanisms through which $O B$ protein acts. The key elements of the OB protein pathway are shown in Figure 1, including a transport system for $\mathrm{OB}$ protein to enter the brain, $\mathrm{OB}$ protein receptors in hypothalamic nuclei, and neural and neuroendocrine outputs to peripheral tissues (Campfield et al. 1996a, 1997a).

In the present review we will discuss the available knowledge about the OB protein pathway within the brain. This understanding is based on in vitro experiments as well as studies conducted in laboratory animals and human subjects. This research has revealed that the $\mathrm{OB}$ protein, by acting on diverse brain structures and mechanisms, regulates ingestive behaviour, metabolism, neuroendocrine rhythms and controls body energy balance. These brain structures and mechanisms form the central $\mathrm{OB}$ protein pathway. The role of $\mathrm{OB}$ protein, the concept of reduced brain sensitivity to $O B$ protein in obesity, and possible therapeutic approaches based on $O B$ protein will also be presented. Finally, the interaction of $\mathrm{OB}$ protein with other brain mechanisms is summarized. The role of OB protein in obesity and the future of neurobiology of $\mathrm{OB}$ protein will also be discussed.

\section{Obesity and the context of the neurobiology of $\mathrm{OB}$ protein}

Obesity is a major health problem throughout the world. Obesity is the most common nutritional disorder in the developed world and is associated with significant chronic metabolic diseases (hypertension, non-insulin-dependent diabetes mellitus, hypercholesterolaemia) as well as stroke, sleep apnoea, joint diseases and certain cancers (Bjorntorp \& Brodoff, 1992). It is a complex multifactorial disease characterized by behavioural, endocrine and metabolic alterations, with an increasing prevalence (Bjorntorp \& Brodoff, 1992; Bouchard \& Perusse, 1993; Thomas, 1995). Obesity is a cause of significant morbidity and is having an increasing negative impact on the health care systems in both developed and developing world (Chadwick \& Cardew, 1996). Although treatment (e.g. diet, exercise, drugs) is available and most people can achieve medically-significant weight loss (5-10\% initial body weight), the long-term maintenance of that weight loss is, unfortunately, very rare. Thus, obesity remains a poorly managed medical condition that is a major cause of morbidity and mortality (Bjorntorp \& Brodoff, 1992; Campfield, 1995; Thomas, 1995; Campfield et al. 1996a, 1997a).

\footnotetext{
Abbreviations: CRH, corticotrophin-releasing hormone; CSF, cerebrospinal fluid; DIO, diet-induced obesity; DIO-R, DIO resistance; NPY, neuropeptide $\mathrm{Y}$; OB-R, OB protein receptor; OB-R , long form of OB-R; OB-Rs, short form of OB-R; POMC, pro-opiomelanocortin.

*Corresponding author: Dr L. Arthur Campfield, fax +1 973235 8128, email L_Arthur.Campfield@Roche.com
} 
Obesity is characterized by the following pathophysiological alterations: (1) high rates of lipid deposition in adipose tissue; (2) reduced insulin sensitivity of muscle and fat; (3) exaggerated insulin responses to meals; (4) hyperinsulinaemia; (5) increased $\mathrm{OB}$ protein concentrations; (6) reduced brain and peripheral sensitivity to $O B$ protein (Thomas, 1995; Campfield et al. 1996a, 1997a).

Ample evidence exists that obesity is, at its basis, a disease of biological dysregulation. The integration of multiple biological factors (including endocrine and metabolic factors), which are at least partially genetically determined, is thought to result in the steady-state body weight of an individual. When the steady-state weight is perturbed in either direction (increased, decreased), changes in body weight are resisted and corrected by robust physiological mechanisms in laboratory rodents and human subjects (Leibel et al. 1995). The physiological mechanisms that resist changes in body fat content (e.g. central neural networks, autonomic neural, metabolic and neuroendocrine) are not completely known (Campfield et al. 1996a, 1997a). It is not understood how these physiological mechanisms are responsible for the unfortunate and very frustrating weight regain that usually follows weight loss. Results of available studies suggest that OB protein acts on the brain and probably plays a role in this 'resetting response' that is responsible for weight regain following weight loss (Campfield et al. 1996a, 1997a).

\section{Control of food intake: a behavioural response dependent on $O B$ protein}

Feeding behaviour is the result of the complex central nervous system integration of central and peripheral neural, hormonal and neurochemical signals relating to brain and metabolic states. Meals are initiated, maintained and terminated by specific sets of these central and peripheral signals several times daily, separated by inter-meal intervals without food intake (Campfield \& Smith, 1990). These signals include patterns of neural afferent traffic, metabolites (glucose), energy flux (fatty acid oxidation, ATP) and hormones (insulin concentrations in plasma and brain; OB protein concentrations in plasma and neuropeptide concentrations in brain). The brain structures and mechanisms involved in the detection of these signals and the mapping of them into altered feeding behaviour are beginning to emerge from the darkness. One hypothesis for this integrated neural, metabolic and hormonal control of food intake postulates the interaction of five classes of signals: (1) hypothalamic neuropeptides; (2) brain insulin; (3) OB protein; (4) metabolic signals, including transient declines in blood glucose concentrations; (5) ascending and descending neural inputs (Bray \& Campfield, 1975; Campfield \& Smith, 1990; Le Magnen, 1992; Campfield et al. 1996a,b). These signals interact and provide the central and/or peripheral integration necessary to regulate food intake and match energy intake to energy expenditure to maintain body energy balance and composition.

Many experimental studies in mice, rats and many other species demonstrate that several neuropeptides modulate food intake when injected centrally and, in some cases, peripherally. The neuropeptides that affect food intake include neuropeptide Y (NPY), galanin, cholecystokinin, corticotrophin-releasing hormone (CRH), and enterostatin (Kaiyala et al. 1995). Synaptic concentrations of central neuropeptides and classical monoamine neurotransmitters are thought to be modulated by the central representations of peripheral metabolic state, and act on post-synaptic receptors to control energy intake (Le Magnen, 1992; Kaiyala et al. 1995). Although some investigators still seek the identity of the 'one' major neuropeptide controlling human feeding behaviour, most of the field has adopted a 'parallel' model in which multiple neuropeptides each play a role in determining human feeding behaviour (Campfield et al. 1997a).

\section{Experimental models of obesity due to altered $O B$ protein pathway: obese $\mathrm{ob} / \mathrm{ob}$ and $\mathrm{db} / \mathrm{db}$ mice}

The obese $o b / o b$ mice were discovered on the C57BL/6J background in 1950 by animal caretakers at the Jackson Laboratories (Bar Harbour, ME, USA). This mutation results in profound obesity. The $d b / d b$ mouse, which arose on the C57BL/KsJ background, is similarly obese and is also characterized by hyperglycaemia. When the ob gene was transferred to the C57BL/KsJ background, an almost identical phenotype to $d b / d b$ mice was observed. Likewise, when the $d b$ gene was transferred to the $C 57 \mathrm{BL} / 6 \mathrm{~J}$ background, an obese phenotype almost identical to $o b / o b$ mice resulted (Coleman \& Hummel, 1973; Herberg \& Coleman, 1977; Coleman, 1978, 1981).

When cross-circulation (or parabiosis) experiments were performed between lean and obese rats by Hervey and colleagues (Hervey, 1971, 1988; Parameswaran et al. 1977) at the University of Leeds (Leeds, UK), the lean partner reduced its food intake and lost weight, while the obese partner continued to gain weight. These studies suggested that the obese partner was producing increased amounts of a factor that was proportional to body fat, and the factor crossed into the circulation of the lean partner where it acted on the brain to reduce food intake and body weight. When cross-circulation (or parabiosis) experiments were performed in $o b / o b$ and $d b / d b$ mice by D. Coleman and colleagues (Coleman, 1973, 1978, 1981; Coleman \& Hummel, 1973; Herberg \& Coleman, 1977) at the Jackson Laboratories, they also observed that the $o b / o b$ partner reduced its food intake and lost weight, while the $d b / d b$ partner maintained both its food intake and body weight. These studies led Coleman $(1973,1978)$ to conclude that $o b / o b$ mice fail to secrete a circulating factor from adipose tissue, but their brain can respond to it and reduce food intake, while $d b / d b$ mice secrete the circulating factor from their adipose tissue, but their brain cannot respond to it. The insightful hypotheses of Hervey $(1971,1988)$ and Coleman $(1973,1978,1981)$ have been proven correct by the findings on the $O B$ protein pathway in the past 3 years. Despite numerous attempts to isolate and identify this protein, the primary defect, the site of synthesis and the nature of the $o b$ gene product were not known until cloning of the $o b$ gene. It remains a great privilege for us to work with these very special animals, $o b / o b$ mice, and to be part of the emerging OB protein story.

A mutation in the $o b$ gene results in severe obesity in mice ( $o b / o b$ mice). In December 1994, in a tour de force of positional cloning, the laboratory of Dr J. M. Friedman succeeded in cloning the $o b$ gene (Zhang et al. 1994). A 


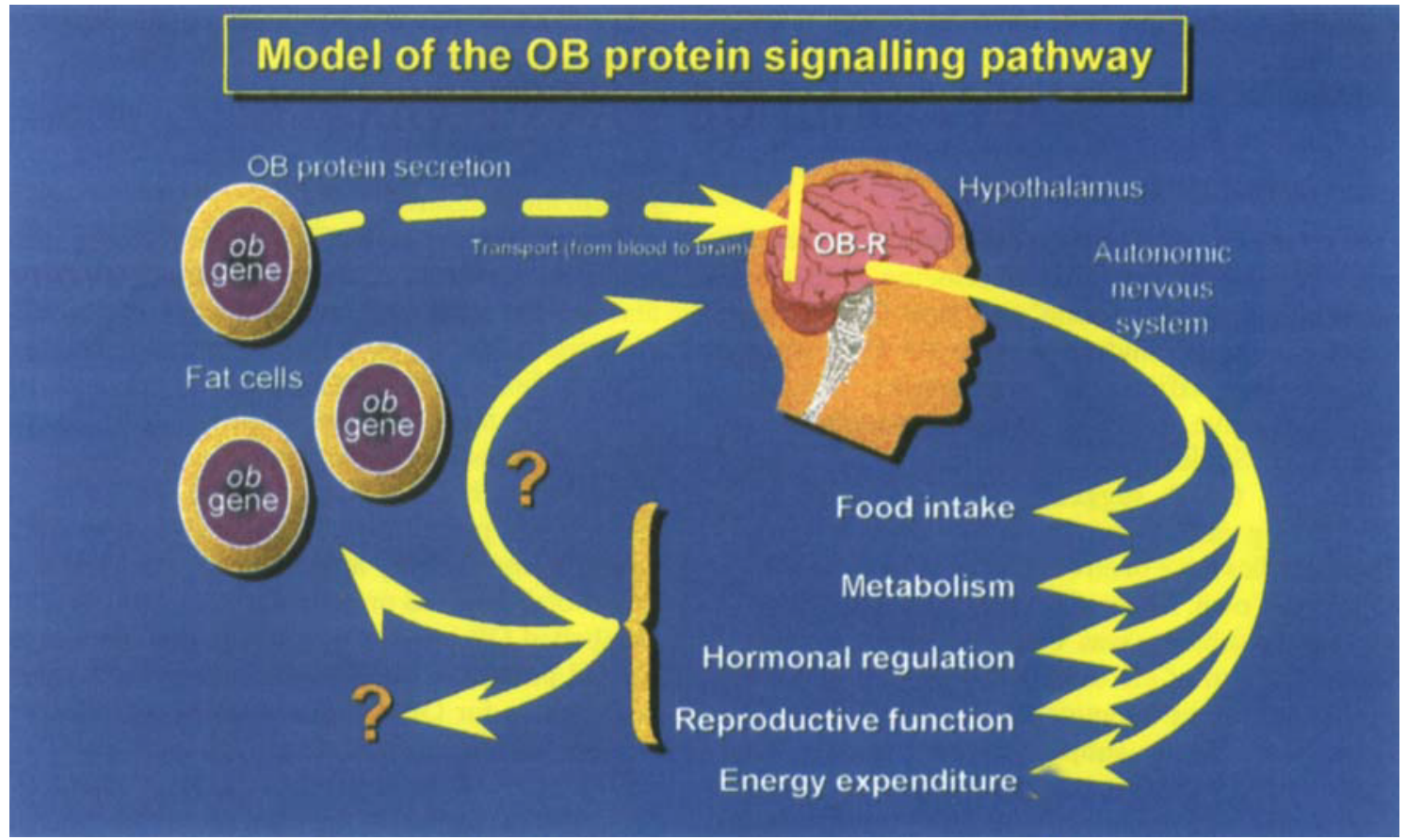

Fig. 1. A schematic model of some of the important elements of the $O B$ protein signalling pathway that regulates body energy balance. $O B-R, O B$ protein receptor. For further, details, see p. 429.

mutation in the $d b$ gene results in severe obesity that is phenotypically similar to that of the $o b / o b$ mice. Following the expression cloning of the OB protein receptor (OB-R) in late 1995 by scientists at Millennium Pharmaceuticals Inc. (Cambridge, MA, USA) and Hoffmann-La Roche (Nutley, NJ, USA) (Tartaglia et al. 1995), three groups demonstrated that the $d b$ gene encodes the OB protein receptor in early 1996 (Chen et al. 1996; Chua et al. 1996; Lee et al. 1996).

After screening the coding region of the $o b$ gene in several thousand obese subjects, two obese cousins with $o b$ gene mutations were identified. These two individuals were normal weight at birth, but both have become severely obese children (Montague et al. 1997). Their identification suggests the operation of an $\mathrm{OB}$ protein pathway in man.

\section{Diet-induced obesity}

A model with potentially more applicability to human obesity is diet-induced obesity (DIO) in mice and rats. When very palatable, high-fat diets (remarkably similar to chocolate chip cookie dough without the chocolate chips; mainly composed of sugar and shortening added to powdered rodent food) are given to normal mice and rats, DIO occurs in approximately $60-75 \%$ of some, but not all, strains of mice and rats. Animals will rapidly gain weight over a 4-6-week period, and have increased circulating concentrations of insulin and $\mathrm{OB}$ protein, and become very obese when fed on these diets (West et al. 1994). These DIO animals, also, will have decreased sensitivity to the actions of circulating insulin and $\mathrm{OB}$ protein. The operational definition for DIO is a body weight $>$ average body weight of animals fed on normal food + two standard deviations. Diets with a high fat content, high energy density, or multiple palatable items that are presented simultaneously (called supermarket or cafeteria diets) can produce DIO in otherwise normal rodents. Strains that 'resist' DIO and its metabolic alterations (e.g. SHR mice) and individual 'resistant' members of a susceptible strain are being studied because they may provide important biological clues to help reduce weight gain, and regain, in susceptible human subjects (West et al. 1994). DIO is an experimental model that is very relevant for studying obesity, particularly with regard to the $\mathrm{OB}$ protein pathway. This is because it offers us a chance to study a polygenic obese state in animals that may mimic the situation in most obese human subjects; the interaction of genetic predisposition, rather than mutation, with the environment.

\section{Important findings from the human biology of $\mathrm{OB}$ protein}

\section{Serum concentrations}

Radioimmunoassays and ELISA assays for human OB protein were rapidly developed (Considine et al. 1996). These studies can be summarized as follows: when obese subjects were compared with lean individuals, it was observed that the serum $O B$ protein concentrations were higher in obese individuals; $O B$ protein concentrations increased with increasing percentage body fat (Maffei et al. 1995; Considine $e t$ al. 1996). Thus, obese human subjects are not deficient in $\mathrm{OB}$ protein, but rather they have elevated circulating $\mathrm{OB}$ protein concentrations. Women have higher OB protein concentrations than men, even when corrected for the percentage body fat. Subjects with non-insulin-dependent diabetes mellitus have lower OB protein levels than obese subjects but higher levels than lean subjects. When obese subjects lost 
weight by energy restriction, $\mathrm{OB}$ protein concentration decreased and then rose slightly when the lower weight was maintained (Considine et al. 1996).

\section{Circulating binding proteins}

A group of scientists at Thomas Jefferson University (Philadelphia, PA, USA) provided convincing evidence, using gel filtration to separate 'bound' and 'free' $O B$ protein, for a family of circulating binding proteins for $O B$ protein (Sinha et al. 1996). Affinity chromatography revealed that these proteins have molecular masses ranging from $40 \mathrm{kDa}$ to $280 \mathrm{kDa}$. Studies with an antibody to the extracellular domain of $\mathrm{OB}-\mathrm{R}$ suggested that approximately $10 \%$ of the binding protein might be the 'soluble form' of OB-R. These studies have been confirmed in many laboratories, including our own. Most of the OB protein in the serum of lean human subjects was bound to other proteins, while the major fraction of circulating OB protein in obese human subjects was in an unbound or free form. When a small number of obese subjects were fasted, the total (free + bound) $\mathrm{OB}$ protein concentration in the serum decreased, with the major change occurring in the free fraction, while the bound fraction remained unchanged (Sinha et al. 1996). The radioimmunoassays used by the Thomas Jefferson University group (Considine et al. 1996), including the commercial radioimmunoassay by Linco (St Charles, MO, USA), and the human OB protein-specific ELISA that we used in the studies summarized previously, all measure the total $\mathrm{OB}$ protein concentrations (Sinha et al. 1996).

\section{Cerebrospinal fluid $O B$ protein concentrations}

Measurements of the concentrations of $O B$ protein in the cerebrospinal fluid (CSF) and the serum, and the calculation of CSF : serum values for OB protein of lean and obese human subjects have been reported, first by Schwartz et al. (1996b) and later by Caro et al. (1996). The CSF concentrations of $\mathrm{OB}$ protein were correlated with BMI, but were much lower than the serum concentrations in individuals studied in both reports (CSF : serum values ranged from 0.01 to 0.15 in the Schwartz et al. (1996b) study and from 0.01 to 0.09 in the Caro et al. (1996) study). Although the serum concentrations of $\mathrm{OB}$ protein were much higher in obese individuals compared with lean subjects, the CSF levels in obese subjects were low and similar to those of lean subjects in both studies. Comparison of the CSF and serum concentrations of $\mathrm{OB}$ protein in the lean and obese subjects reveals that OB protein concentrations were much lower in obese subjects than in lean subjects (mean CSF : serum values were 0.013 (SE 0.001) in obese subjects and 0.068 (SE 0.01) in lean subjects in the Schwartz et al. (1996b) study and were 0.011 (SE 0.002) in obese subjects and 0.047 (SE 0.001) in the lean subjects in the Caro et al. (1996) study). Thus, when obese and lean subjects are compared, the appearance of OB protein within the CSF is much lower than expected and is not proportional to the serum concentration, given the elevated concentrations of total $\mathrm{OB}$ protein. This observation has led to the suggestion that the brain uptake of $\mathrm{OB}$ protein and/or its appearance in the CSF compartment is defective in obese subjects and it may be a component of the decreased sensitivity to OB protein (Caro et al. 1996; Schwartz et al. 1996b). However, this suggestion may have to be reconsidered as the role of the circulating binding proteins is elucidated and the serum concentrations and CSF concentrations of 'free' OB protein are measured.

Like much else in the $O B$ protein pathway, the functional significance of low CSF concentrations of OB protein must also await additional experiments conducted in human subjects. However, the transport of radiolabelled OB protein into the brain of mice has been reported by Banks et al. (1996). In these studies, radiolabelled OB protein was injected intravenously into mice and autoradiography was conducted in brain sections after the mice were killed. They showed the presence of ${ }^{125} \mathrm{I}$ in the arcuate nucleus of the hypothalamus shortly after the injection. The rate of uptake of radiolabelled $\mathrm{OB}$ protein was decreased by co-injection of unlabelled $O B$ protein, suggesting that the transport system for $O B$ protein in mice may be saturable. A saturable transport system for $O B$ protein in isolated human brain microvessels has been discovered and reported (Golden et al. 1997). Many of the features of the brain transport system for OB protein appear to be similar to the transport system already described for brain insulin (Schwartz et al. 1991, 1994; Kaiyala et al. 1995).

\section{Properties of $\mathrm{OB}$ protein and biological activity of $\mathrm{OB}$ protein in mice and rats}

Some of the major properties of OB protein are as follows: the signal sequence in front of the sequence for $O B$ protein is cleaved and the mature $\mathrm{OB}$ protein is secreted into the circulation. $\mathrm{OB}$ protein is a $16000 \mathrm{Da}$ monomeric protein. The $\mathrm{C}$ terminal disulfide bond appears to be critical for the activity of $\mathrm{OB}$ protein. In addition, $\mathrm{OB}$ protein has homology to the class I cytokine family. Finally, the $o b$ gene is expressed in adipose tissue, bone marrow and placenta, and $\mathrm{OB}$ protein is synthesized and secreted from adipose tissue in proportion to adipocyte size and number (Campfield et al. 1996a, 1997a).

\section{Biological activity of $O B$ protein in mice and rats}

To determine if the brain was a target of $\mathrm{OB}$ protein, we injected recombinant mouse $\mathrm{OB}$ protein intracerebroventricularly (lateral ventricle) to $o b / o b$ and lean ( $( \pm)$ mice in our first study of the biological activity of OB protein (Campfield et al. 1995). These mice were implanted with chronic lateral ventricle cannulas. Single intracerebroventricular injections of $0.001-1 \mu \mathrm{g} /$ mouse in $1 \mu \mathrm{l}$ were administered to overnight fasted $o b / o b$ and lean $( \pm)$ mice. Cumulative $7 \mathrm{~h}$ and $24 \mathrm{~h}$ food intake values were suppressed in a dose-related manner. Post-injection body-weight gains were also reduced in a dose-related manner compared with mice injected with vehicle control (Campfield et al. 1995).

However, when the effective dose in lean rats $(3.5 \mu \mathrm{g})$ of OB protein was placed in the third ventricle in obese Zucker rats, no behavioural effects were observed (Seeley et al. 1996). In contrast, Rohner-Jeanrenaud et al. (1996) and Lin et al. (1996) reported that higher doses of OB protein did suppress food intake of obese Zucker rats. Further studies 
will be needed to determine the impact of the point mutation in the OB-R of the obese Zucker rat on its sensitivity to OB protein.

When a compound, peptide or protein, administered peripherally or centrally results in reduced food intake and the loss of body weight, the possibility that these behavioural effects are due to non-specific action or illness produced by the test substance must be considered. In order to assess this possibility for the biological effects of $\mathrm{OB}$ protein, a conditioned taste aversion experiment was conducted (Thiele $\mathrm{et} \mathrm{al}$. 1997). In these studies, lean Long-Evans rats were offered two drinking bottles containing saccharin solution or water daily for several days. The presentation of saccharin was paired with the intracerebroventricular injection of $\mathrm{OB}$ protein, the intraperitoneal injection of $\mathrm{LiCl}$ or no treatment. As expected, treatment with a known toxin, $\mathrm{LiCl}$, caused striking rejection of the consumption of saccharin, the taste associated with $\mathrm{LiCl}$ treatment, but had no effect on the consumption of water. This decreased preference for a taste paired with a toxic substance is called a conditioned taste aversion. In contrast, intracerebroventricular treatment with OB protein had no effect on the consumption of saccharin or water. These studies demonstrate that $O B$ protein does not support the development of a conditioned taste aversion. These results provide strong support for the idea that the reduction in food intake and body weight observed following the administration of $\mathrm{OB}$ protein are specific biological effects of the hormone (Thiele et al. 1997).

The results of these experiments, taken together, provide further support for the hypothesis that a circulating proteinbased signal, secreted from adipose tissue, acts on central neuronal networks, and suggests that OB protein plays an important role in the regulation of ingestive behaviour and energy balance. The duration of action of $\mathrm{OB}$ protein appears longer than that of other neuropeptides which modulate ingestive behaviour (cholecystokinin, NPY, galanin), and is similar to that of centrally-administered insulin. The brain-insulin system is the other well-established system that signals adiposity to the brain (Kaiyala et al. 1995). The behavioural and physiological effects following central administration of $\mathrm{OB}$ protein into the lateral ventricle suggest that $O B$ protein can act directly on the neural networks in the brain that regulate ingestive behaviour and energy balance.

\section{OB protein receptor}

Several significant results were achieved that led to the rapid identification and characterization of OB-R. First, was our demonstration that central administration of $\mathrm{OB}$ protein results in reductions in food intake, body weight and alterations in metabolism. These findings were confirmed by others (Stephens et al. 1995). Second, scientists at Hoffmann-La Roche, Millennium Pharmaceuticals Inc., and others, identified a central binding site for labelled $O B$ protein in the choroid plexus and pia mater in $o b / o b, d b / d b$ and lean mice as well as lean and obese Zucker rats (Devos et al. 1996; Lynn et al. 1996). Based on this identification, researchers at Millennium Pharmaceuticals Inc. and Hoffmann-La Roche succeeded in the expression cloning of a central receptor, OB-R, from the mouse choroid plexus in December 1995 (Tartaglia et al. 1995).
OB-R had considerable homology with the GP130 subunit of the IL-6 receptor. It was concluded that the OB-R has significant homology to a cytokine receptor (Tartaglia et al. 1995). OB-R was found to be expressed in the choroid plexus, the hypothalamus and many other brain areas as well as several peripheral tissues (Ghilardi et al. 1996; Mercer et al. 1996). However, OB-R is a low-abundance message and protein, making unambiguous detection of the receptor message and protein difficult. As a result of alternate splicing, OB-R exists in multiple forms. The two major forms are a short form (OB- $R_{S}$, with a truncated intracellular domain) and a long form (OB- $\mathrm{R}_{\mathrm{L}}$, with the complete intracellular domain). OB- $\mathrm{R}_{\mathrm{L}}$ is thought to be the form that signals and mediates the biological effects of OB protein (Tartaglia et al. 1995). In situ hybridization studies have demonstrated that the mRNA for OB- $\mathrm{R}_{\mathrm{L}}$ is localized primarily to the hypothalamus (arcuate, lateral, ventromedial, dorsomedial nuclei; Mercer et al. 1996; Schwartz et al. 1996c). Soon it was demonstrated that the $d b$ gene encodes the OB-R (Chen et al. 1996; Chua et al. 1996; Lee et al. 1996). Point mutations have been identified in the OB-R in obese $d b / d b$ mice (no $\mathrm{OB}-\mathrm{R}_{\mathrm{L}}$ ), obese Zucker (extracellular domain) and corpulent rats (no mRNA for OB-R). The molecular biology and characterization of $\mathrm{OB}-\mathrm{R}$ has been recently reviewed by our colleague, Dr L. Tartaglia (Tartaglia, 1997; White \& Tartaglia, 1997).

\section{Role of $\mathrm{OB}$ protein in obesity and the concept of reduced sensitivity to $\mathrm{OB}$ protein in obesity}

Most human obesity is probably not due to a deficiency of OB protein, but instead due to a central and/or peripheral resistance or decreased sensitivity to OB protein. Support for the concept of reduced sensitivity to $O B$ protein in obesity is based on the available results in animal models and human subjects, summarized previously (Campfield et al. 1995; Considine et al. 1996). This is very similar to the case of the insulin-resistant obese patients with non-insulin-dependent diabetes mellitus. However, positive clinical experience with insulin therapy in these patients and our positive results with OB protein treatment of DIO mice (Campfield et al. 1995) strongly suggest that therapeutic augmentation of circulating OB protein levels may result in reductions of food intake, body fat mass and body weight in many obese patients (Campfield et al. 1996a, 1997a).

Strong support for the concept of reduced sensitivity to OB protein in obesity is provided by the observation of elevated $\mathrm{OB}$ protein concentrations in the blood of obese individuals and the experimental result that higher doses are required to affect feeding behaviour, metabolism and body fat in DIO mice (Campfield et al. 1995; Considine et al. 1996). At one extreme of the continuum of $O B$ protein responsiveness is the obese $d b / d b$ mouse, with elevated $\mathrm{OB}$ protein levels, which is totally unresponsive to $\mathrm{OB}$ protein, while at the other end is the very responsive $O B$ proteindeficient, obese $o b / o b$ mouse, as shown in Fig. 2. Although these two mutant mice with defects in the $O B$ protein pathway anchor the continuum of $\mathrm{OB}$ responsiveness shown in Fig. 2, they have, in our opinion, little relevance to human obesity. Although DIO mice are less responsive than lean mice, they still retain a significant responsiveness to $O B$ 


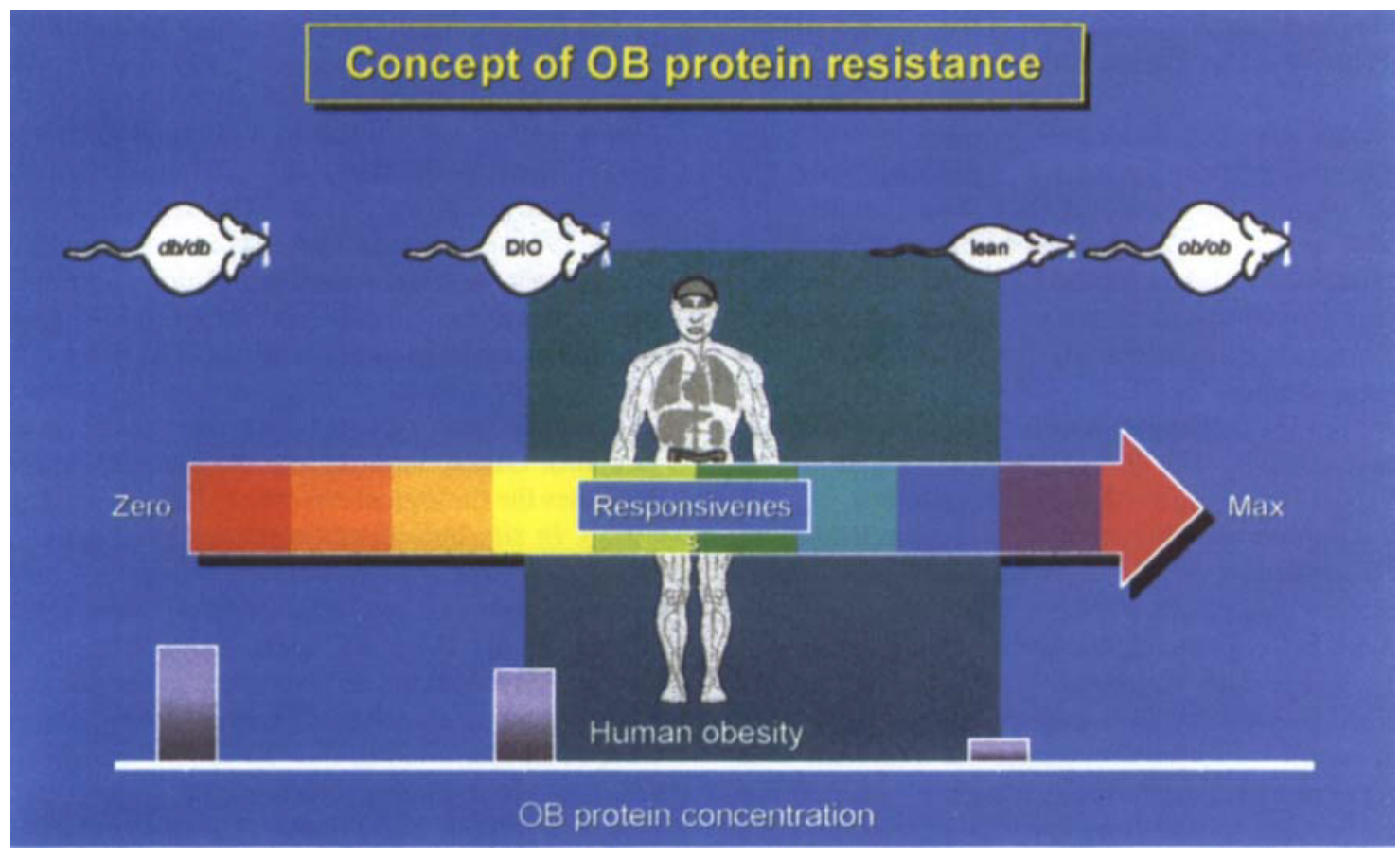

Fig. 2. The concept of $O B$ protein resistance. Mice with different sensitivity to $O B$ protein define the range of responsiveness to $O B$ protein. At one extreme are the $\mathrm{OB}$ protein-deficient, obese $o b / o b$ mice that are maximally responsive, while at the other end are the obese $d b / d b$ mice, with elevated $\mathrm{OB}$ protein levels, which are totally unresponsive to $\mathrm{OB}$ protein. In the middle, lean and obese diet-induced obese (DIO) mice are shown. Although obese DIO mice are less responsive that lean mice, they still retain a significant responsiveness to OB protein. The OB protein responsiveness of obese human subjects is assumed to range from normal to decreased, but still responsive. Relative plasma OB protein concentrations are shown for unresponsive obese $d b / d b$ mice (high), DIO mice with reduced responsiveness (elevated), lean mice (normal) and maximally responsive obese ob/ob mice (zero). (Reprinted from Campfield et al. 1996a.)

protein (Campfield et al. 1995). The OB protein responsiveness of most obese humans will probably range from normal to decreased, but still responsive, as indicated in Fig. 2 . Whether the reduced sensitivity to $O B$ protein is due to one or more intrinsic or regulatory defects in the post-receptor signalling pathway or/and decreased brain transport and uptake of OB protein remains to be determined by further research (Banks et al. 1996; Golden et al. 1997).

Movement of mice along the continuum of $\mathrm{OB}$ protein sensitivity as a function of adiposity, as shown in Fig. 2, has been demonstrated in our recent studies of DIO mice. When lean $A K R / J$ mice are fed on a high-fat energy-dense diet, they become obese, with elevated $\mathrm{OB}$ protein and insulin concentrations. Our demonstration that DIO AKR/J mice required higher intraperitoneal doses of $\mathrm{OB}$ protein to reduce food intake contributed to the concept of OB protein resistance. Recently, we have shown that DIO mice have decreased central sensitivity to $\mathrm{OB}$ protein (Campfield $e t$ al. $1997 b$ ). In these studies we determined the sensitivity to intracerebroventricular injection of mouse $O B$ protein in DIO mice after changes in diet. Female mice were fed on a high-fat diet for 13 weeks and then switched to chow for 2 weeks. We measured $6 \mathrm{~h}$ food intake following intracerebroventricular administration of OB protein to DIO mice as well as lean mice, and non-obese mice on the same high-fat diet (DIO-R). After 13 weeks on the high-fat diet, serum insulin and $\mathrm{OB}$ protein levels were markedly increased in DIO mice. When $1 \mu \mathrm{g}$ OB protein was injected intracerebroventricularly, food intake suppression was similar in lean and DIO-R mice ( $43 \%$ ), but was markedly reduced in DIO mice $(23 \%)$. After 2 weeks on chow, DIO mice had reduced body weight to the range of body weight of DIO-R mice, and now intracerebroventricular $\mathrm{OB}$ protein reduced food intake similarly in lean and DIO-R and formerly DIO mice (53\%), indicating an increase in brain sensitivity to $O B$ protein in formerly DIO mice. These results demonstrate that expansion of the adipose tissue mass, as a result of high-fat diet feeding, is associated with decreased brain sensitivity to OB protein injected intracerebroventricularly. In contrast, decreased brain sensitivity to $O B$ protein was not observed in mice remaining lean while on high-fat diet. Thus, these studies with DIO mice indicate that the brain sensitivity to OB protein of the neural network in the brain controlling energy balance is decreased by weight gain and can be reversed by weight loss (Campfield et al. 1997b).

The biological effects of daily peripheral administration of recombinant human $\mathrm{OB}$ protein or an analogue of human OB protein in lean and obese human subjects are currently being determined in clinical trials being conducted by Amgen (Thousand Oaks, CA, USA) and Eli Lilly (Indianapolis, IN, USA) respectively. In a press release, Amgen stated that weight loss was observed after daily subcutaneous injections of $\mathrm{OB}$ protein in obese subjects. The publication of the results of these trials is eagerly awaited by the obesity research community and obese individuals.

Each advance in our understanding of the $O B$ protein brings us closer to the development of an effective and safe drug that will increase the sensitivity of the $\mathrm{OB}$ pathway in 
brain of obese individuals to their own more-than-adequate levels of OB protein (Campfield et al. 1996a, 1997a). Such an increase in the sensitivity of the OB protein pathway to their OB protein should assist them to reduce and then chronically maintain a lower amount of body fat that will result in improved health (Thomas, 1995; Campfield, 1996).

\section{Interaction of $\mathrm{OB}$ protein with other brain hormones and neuropeptides}

Research on the brain mechanisms involved in OB protein action has been stimulated by the long-lasting reductions in food intake and body weight of obese $o b / o b$ mice observed following intracerebroventricular OB protein administration (Campfield et al. 1995; Stephens et al. 1995), together with the observation that the circulating $\mathrm{OB}$ protein concentration was proportional to body fat in human subjects (Considine et al. 1996). Central administration of OB protein reduced food intake and body weight, altered metabolism and inhibited NPY-induced feeding of obese $o b / o b$ mice and lean mice and rats (Campfield et al. 1995; Stephens et al. 1995; Hwa et al. 1996; Smith et al. 1996).

Some of the recent advances in the neurobiology of $\mathrm{OB}$ protein are listed in Table 1. The neurotransmitters and neuropeptides that directly mediate the actions of $\mathrm{OB}$ protein have not yet been identified, but experimental evidence is consistent with $\mathrm{OB}$ acting through several brain mechanisms (NPY, CRH, pro-opiomelanocortin (POMC)) to co-ordinate the regulation of energy balance. Which, if any, neurotransmitters and neuropeptides are responsible for the decreased sensitivity to $\mathrm{OB}$ protein in obesity are not known. However, the neuronal network controlling energy balance and the descending sympathetic nervous system following peripheral and central administration of $\mathrm{OB}$ protein is beginning to emerge.

Patterns of activation of brain areas in response to central or peripheral administration of $\mathrm{OB}$ protein have been measured using $c$-fos immunoreactivity. Numerous studies have implicated hypothalamic nuclei (arcuate, ventromedial hypothalamus, dorsomedial hypothalamus, paraventricular nucleus) and other brain areas thought to be involved in the control of energy balance (van Dijk et al. 1996; Thiele et al. 1997; Yokosuka et al. 1997).

Early in the story of $\mathrm{OB}$ protein it was proposed that NPY, a potent stimulator of feeding (Ezzell, 1995; RohnerJeanrenaud et al. 1996; Rohner-Jeanrenaud \& Jeanrenaud, 1996), was the major mediator of the actions of OB protein (Stanley et al. 1986; Ezzell, 1995; Stephens et al. 1995). This proposal was based on the inhibitory effects of $O B$ protein on NPY gene expression (Stephens et al. 1995; Schwartz et al. 1996a) and secretion (Stephens et al. 1995) observed in early studies of the biological activity of $\mathrm{OB}$ protein. We examined the interaction of brain administration of $\mathrm{OB}$ protein and NPY on the feeding behaviour of $o b / o b$ mice to test this hypothesis. We found that $\mathrm{OB}$ protein inhibited the expected feeding following NPY administration. The magnitude and time course of food intake were determined by the presence of $O B$ protein. Although the stimulatory actions of NPY on feeding were dominated by OB protein, the increased food intake following combined $\mathrm{OB}$ protein and
Table 1. Recent progress in neurobiology of $\mathrm{OB}$ protein

Studies of neural activation by central and peripheral OB protein using $c$-fos-like activity in brains of mice and rats

Co-localization studies of OB-R- and NPY- or POMC-containing hypothalamic neurones

Clear evidence that $\mathrm{OB}$ protein modulates $n p y, c r h$, and pomc gene expression in hypothalamic neurones

Recording of specific peripheral autonomic neural activity following intravenous $\mathrm{OB}$ protein administration in rats

Demonstration that $\mathrm{OB}$ protein modulates synaptic transmission in hypothalamic neurones (intact and slices)

Demonstration that central sensitivity of $\mathrm{OB}$ protein is a function of glucocorticoid status

Interactions between $\mathrm{OB}$ protein pathway and melanocortin signal pathways under active investigation

Identification of receptor-mediated transport of $O B$ protein by brain microvessels

Further evidence that brain uptake and/or transport of OB protein is reduced in obesity

Demonstration that central and peripheral sensitivity to $O B$ protein is reduced in DIO rats and mice

Localization of $O B-R_{L}$ in hypothalamic neurones; but majority in intracellular compartment

Further support that OB protein modulates 'hypothalamicpituitary-target organ' axis

Clear evidence that $\mathrm{OB}$ protein plays a role in the control of reproduction

Identification of two obese cousins with ob gene mutations suggests operation of $\mathrm{OB}$ protein pathway in man

Further appreciation of the pulsatile and circadian rhythms of serum $\mathrm{OB}$ protein concentrations

NPY, npy, neuropeptide Y; POMC, pomc, pro-opiomelanocortin; crh, corticotropin-releasing hormone; DIO, diet-induced obese; OB-RL, long form of $\mathrm{OB}$ protein receptor.

NPY administration indicated that NPY was still acting at its post-synaptic receptors.

These results suggest that $\mathrm{OB}$ protein determines the sensitivity of the feeding response to exogenous NPY. OB protein, when placed into the lateral ventricle, may alter the binding of exogenous NPY to its receptors that are critical for feeding and/or may inhibit downstream signal transduction (Smith et al. 1996). This indicates that OB protein can functionally antagonize the actions of exogenous NPY and suggests that the receptor-mediated actions of NPY on feeding are under the control of OB protein. Thus, it appears that NPY interacts, particularly in the early post-injection period, with $\mathrm{OB}$ protein or $\mathrm{OB}$ protein-dependent signalling processes that contribute to the regulation of body energy balance. However, our results are also consistent with other mediators, besides NPY, of OB protein action. This possibility has been strengthened by the report that normal-weight mice lacking NPY respond to peripheral administration of OB protein (Erickson et al. 1996a). Similar results have been reported recently (Stricker-Krongrad et al. 1996). When both the $a b$ and npy loci were disrupted in mice, the doubleknockout mice were still obese but the degree of obesity was attenuated by about $25-40 \%$. These authors conclude that OB protein-mediated antagonism of the hypothalamic NPY system is required for normal regulation of body energy balance (Erickson et al. 1996b).

When $O B$ protein was administered into the third ventricle of the brain of lean rats, NPY gene expression in the arcuate nucleus was decreased, while CRH gene expression in the paraventricular nucleus was increased (Schwartz et al. 
1996c). Since CRH inhibits feeding of rodents when administered intracerebroventricularly (Schwartz et al. 1994; Kaiyala et al. 1995), these results suggest that part of the activity of $\mathrm{OB}$ protein to inhibit feeding may be mediated through decreased NPY and increased CRH protein levels in hypothalamic nuclei critical for the regulation of food intake and body energy balance. Recent studies also indicate that central administration of $\mathrm{OB}$ protein increases the expression of the POMC gene in the arcuate nucleus (Schwartz et al. 1997).

Co-localization studies using selective antibodies have demonstrated that $\mathrm{OB}$ protein acts through OB-R on neurones that contain NPY, adrenocorticotrophic hormone, $\mathrm{CRH}$, POMC, somatostatin, galanin, tyrosine hydrolase (EC 1.14.16.2), and melanocyte-concentrating hormone (Hakansson et al. 1998). These findings support an integrative role for $\mathrm{OB}$ protein and/or the $\mathrm{OB}$ protein pathway.

The long duration of food intake suppression induced by OB protein in obese $o b / o b$, lean and DIO mice (Campfield $e t$ al. 1995) was reminiscent of the effects of central administration of insulin. Studies to test this hypothesis are currently underway in many laboratories, including ours. The striking finding that adrenalectomy can restore sensitivity of obese Zucker $(f a / f a)$ rats to centrally-administered insulin (Kaiyala et al. 1995), the well-established effects of glucocorticoids in animal models of obesity (Bray \& York, 1979), and the actions of $\mathrm{OB}$ protein on the hypothalamic- pituitary-adrenal axis in fasted mice (Ahima et al. 1996), suggested that $O B$ protein may interact with the glucocorticoid system. In a series of experiments in which $O B$ protein was administered centrally in adrenalectomized and sham-operated lean rats, a marked shift of the OB protein dose-response curve for the reduction of food intake to the left was observed in adrenalectomized rats (Zakrzewska et al. 1997). These preliminary results provide support for a potentially important interaction between $\mathrm{OB}$ protein and the glucocorticoid system (Campfield et al. 1996a, 1997a).

$O B$ protein is not only linked to the regulation of energy balance but also may have a number of additional roles, such as maintaining the normal neuroendocrine activity that is important in the adaptation to starvation and controls stress responses and functions such as reproduction. Starved mice and $\mathrm{OB}$ protein-deficient $o b / o b$ mice were found to have similar neuroendocrine abnormalities, including an activated hypothalamic-pituitary-adrenal response and depressed thyroid function. In addition, male mice had low levels of testosterone and delayed ovulation was observed in female mice. When fasted mice were treated with $\mathrm{OB}$ protein, these neuroendocrine abnormalities were reversed (Chehab et al. 1996). Administration of OB protein to female $o b / o b$ mice restored reproductive function to near normal, and the mice became pregnant and successfully carried litters to term (Chehab et al. 1996).

It has been demonstrated that $\mathrm{OB}$ protein could modulate synaptic transmission when applied to hypothalamic slice preparations from rat brain. This report suggested another mechanism to explain the behavioural and metabolic actions of OB protein (Glaum et al. 1996). Direct administration of OB protein on glucose-receptive ATP-sensitive K channels resulted in hyperpolarization of hypothalamic neurones (Spanswick et al. 1997). Direct application of OB protein to ventromedial hypothalamus and luteinizing hormone neurones resulting in both stimulation and inhibition of firing rates have been reported (Yokosuka et al. 1997). Future neurophysiological research will help evaluate if $O B$ protein has a neuromodulatory action.

\section{Role of the $O B$ protein pathway in the brain}

One possible role for OB protein is that of a modulator of gene expression, and the resultant synthesis of one or more neurotransmitters and/or neuropeptides within the brain. Much of the research conducted on the OB protein pathway has been focused on the identification of downstream genes that are regulated by $\mathrm{OB}$ protein. Three such genes are npy, crh and pomc, since OB protein has been shown to decrease the mRNA for NPY and increase POMC mRNA and the mRNA for $\mathrm{CRH}$ in different areas of the hypothalamus (Campfield et al. 1996a, 1997a).

Another possible role for OB protein is that of a modulator of synaptic transmission within the brain. This could involve alteration of the release or post-synaptic action of one or more neurotransmitters and/or neuropeptides and/or states of one or more presynaptic and/or post-synaptic ion channels. Since recent electrophysiological studies have demonstrated this hypothesis is correct (Glaum et al. 1996; Spanswick et al. 1997), then behavioural and metabolic responses to the administration of $\mathrm{OB}$ protein may be expected to depend on the 'background' amounts of these neurotransmitters and/or neuropeptides in synapses or nerve terminals. Since the amounts of these neurotransmitters and neuropeptides change with time, variability in either behavioural and/or metabolic responses to administration of $\mathrm{OB}$ protein would be expected. However, in our experiments with sequential administration of OB protein and NPY (described previously), we were impressed with the very reproducible, rather than variable, nature of these interaction data (Smith et al. 1996).

Another alternative role for $\mathrm{OB}$ protein would be a 'co-ordinator' or 'organiser' of the seemingly disparate neurotransmitter and neuropeptide effects on, and responses to, ingestive behaviour and body energy balance. The recent demonstration of 'co-ordinated' response of NPY, POMC and $\mathrm{CRH}$ gene expression (inhibition of NPY mRNA and increased POMC mRNA in arcuate nucleus and increased CRH mRNA in the paraventricular nucleus in response to central administration of $\mathrm{OB}$ protein) provides support for this concept. These responses were 'co-ordinated' in both space (two different anatomical locations) and time (both changes were seen at a common time point that was correlated with the behavioural response; Campfield et al. 1996a, 1997a).

These three possible roles do not have to be, and are probably not, mutually exclusive. Indeed, the 'co-ordinator' or 'organizer' function of $\mathrm{OB}$ protein within the brain may emerge from at least two distinct regulatory components mediated by OB-R as shown in Fig. 3: (1), the action of OB protein to regulate gene expression within areas of the brain critical for regulation of energy balance (Fig. 3) can be considered responsible for the 'long-term' or 'chronic' biological effects (e.g. critical molecules which determine the brain sensitivity to OB protein, 'settling point' for body fat 


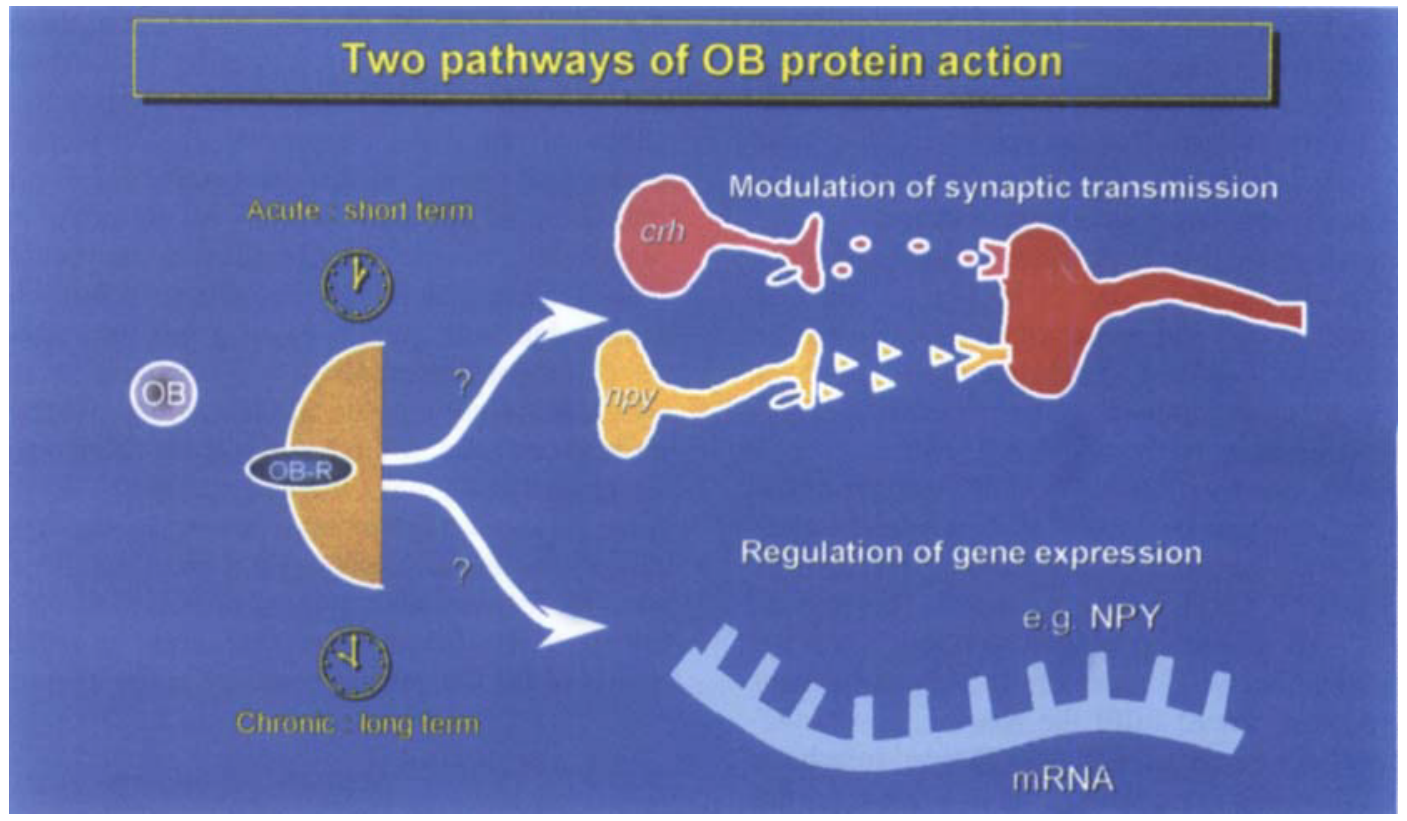

Fig. 3. Schematic representation of two pathways of $O B$ protein action. (OB, OB protein; $\odot-A$, OB protein receptor. OB protein action is a combination of acute actions mediated by modulation of synaptic transmission and chronic actions mediated by regulation of gene expression. $\mathrm{CRH}$, $\mathrm{crh}$, corticotrophin-releasing hormone; NPY, npy, neuropeptide Y. (Reprinted by permission from Campfield et al. 1997a.)

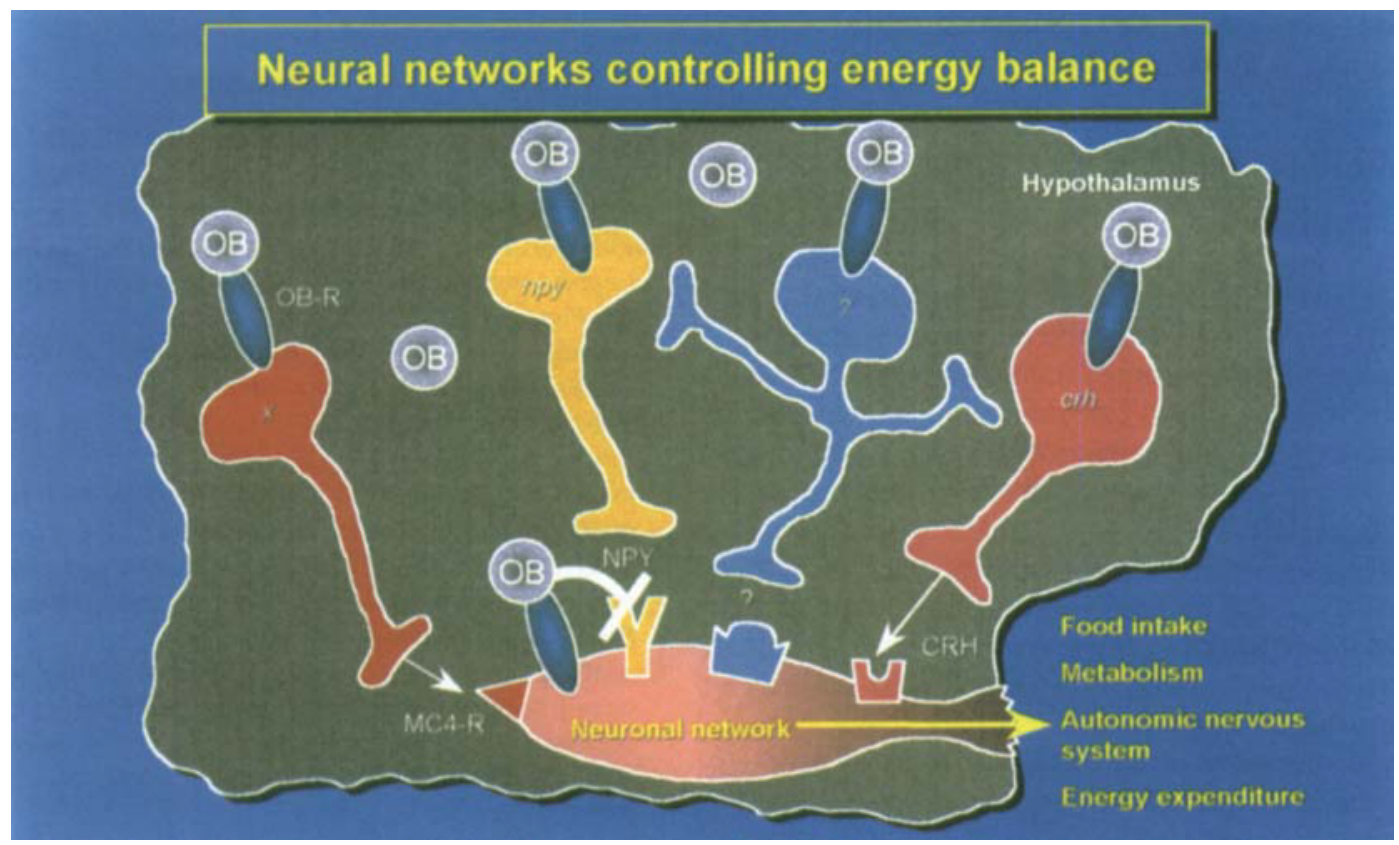

Fig. 4. Schematic diagram of hypothetical neural networks controlling energy balance. Several 'classes' of parallel neural pathways are represented by the four model neurones depicted. Each neurone is assumed to have the gene, synthesize and release one dominant type of neuropeptide: neuropeptide $Y$ (NPY, npy), corticotropin-releasing hormone $(\mathrm{CRH}, c r h), X$ (pro-opiomelanocortin; POMC), ?. Each neurone has the long form of the OB protein receptor (OB-R; $\longrightarrow$ ) and the 'final common pathway', the neuronal network controlling ingestive behaviour, metabolism and energy balance, has distinct receptors for $\mathrm{OB}, \mathrm{NPY}, \mathrm{CRH}, \mathrm{X}(\mathrm{POMC})$ and ?. ( 9 , $\mathrm{OB}$ protein. Note that $\mathrm{OB}$ protein can express its biological action through five parallel paths, each mediated by a different neuropeptide: NPY, CRH, POMC, or '?'. The ability of OB protein to inhibit the actions of released NPY is also shown. MC4-R, melanocortin 4 receptor. (Reprinted from Campfield et al. 1997a.)

content); (2), the action of OB protein to modulate synaptic transmission within the brain by altering the release or postsynaptic action of one or more neurotransmitters and/or neuropeptides and/or states of one or more presynaptic and/ or post-synaptic ion channels (Fig. 3) can be considered responsible for the 'short-term', 'acute' or 'immediate' behavioural (suppression of food intake) and metabolic effects (decreased serum concentrations of insulin and glucose). This 'dual-function' mechanism of action, regulation of gene expression and modulation of ongoing cellular function such 
as neurosecretion, is a common and classical property of hormones. If additional experiments support this 'dual-function' mechanism of action for OB protein, it would provide additional evidence for the concept that OB protein is a hormone that plays a critical role in the regulation of brain mechanisms involved in the regulation of energy balance.

One representation of this hypothesis at the molecular level in the hypothalamus is shown in Fig. 4. Several 'classes' of parallel neural pathways are represented by the four model neurones depicted. Each neurone shown is assumed to have the gene, synthesize and release one dominant type of neuropeptide, NPY, CRH, X(POMC), ?. Each neurone has $\mathrm{OB}-\mathrm{R}_{\mathrm{L}}$ (the long form of $\mathrm{OB}-\mathrm{R}$ ), and the "final common pathway', the neuronal network controlling ingestive behaviour, metabolism and energy balance, has distinct receptors for OB, NPY, CRH, X(POMC) and ?. The demonstrated ability of OB protein to inhibit responses to NPY is shown, blocking the NPY receptor. In this theoretical construct, $\mathrm{OB}$ protein would fulfil the role of 'conductor' integrating the distinct 'sections' of the 'orchestra' to behave as one while it plays the "symphony". In this analogy, the 'symphony' is the integrated behavioural, neuroendocrine and metabolic response of an individual, the 'orchestra' is the spatially-distributed neural network controlling ingestive behaviour, metabolism and energy balance, and the 'sections' would be the elements and subsystems of this neural network. This attractive hypothesis must await experimental testing in future studies.

\section{The future of the neurobiology of $\mathrm{OB}$ protein}

The rapid characterization of the $O B$ protein signal pathway within the brains of laboratory rodents and human subjects has been significant for several reasons. OB protein has also demonstrated that the neurobiology and neuroendocrinology of ingestion, metabolism and energy balance have moved to the front of the research agenda. The unravelling of the brain mechanisms underlying the behavioural and metabolic actions of $\mathrm{OB}$ protein and responsible for the sensitivity of the brain to $\mathrm{OB}$ protein has become a major objective of neuroscience, neuroendocrinology and obesity research. The rapid evolution of the $O B$ protein pathway has provided a series of important advances in the knowledge base of this field. This increasing knowledge base should help to prise open and shine a bright light onto the very dark 'black box' that contains the mechanisms and decision rules or algorithms used in the brain for determining the level at which body fat content is regulated in the brains of man and other animals. When these mechanisms are understood at the molecular level, they will provide novel targets for discovery and development of new, safe, effective pharmacological treatment for obesity as adjuncts to diet and exercise in the future. It is hoped that these new therapeutic agents will reduce and maintain body fat at reduced levels and, therefore, increase metabolic fitness, reduce risk factors and promote improved health of obese individuals.

The numerous papers on OB protein published in the last 3 years, some, but not all, of which are discussed and specifically cited in the present review, clearly demonstrate the intense interest within the global biomedical community in the rapidly emerging field of the OB protein neurobiology, the OB protein pathway, and its potential therapeutic applications for the treatment of obesity. These research findings also demonstrate the enthusiasm, excitement, intensity and talent of the basic scientists and clinical investigators throughout the world that are committed to unravelling the regulation of the secretion and the hormonal actions of $\mathrm{OB}$ protein and, eventually, illuminating the mechanisms in the brain responsible for the regulation of body fat. This new knowledge will greatly expand our understanding of the development, maintenance and treatment of obesity, and it should certainly provide additional hope for the many obese individuals who struggle on a daily basis to maintain the weight loss they have worked so hard to achieve. We continue to await experimental testing of the hypotheses presented here in our laboratories, as well as those of others, and we look forward with great anticipation to the surprises and unexpected twists and turns that surely lie ahead as the elucidation of the $\mathrm{OB}$ protein pathway in the brain continues.

\section{Acknowledgements}

We thank Jack F. R. Curtis for assistance with the conceptualization and execution of the artwork. We also thank our departmental colleagues and many collaborators for stimulating discussions and suggestions, and Dr Paul Burn and Dr Denis Loh for their interest and support.

\section{References}

Ahima RS, Prabakaren D, Mantzoros C, Ou D, Lowell B, Maratzoros-Flier E \& Flier J (1996) Role of leptin in the neuroendocrine responses to fasting. Nature 382, 250-252.

Banks WA, Kastin AJ, Huang W, Jaspan JB \& Maness LM (1996) Leptin enters the brain by a saturable system independent of insulin. Peptides 17, 305-311.

Bjorntorp P \& Brodoff BN (editors) (1992) In Obesity. Philadelphia, PA: J. B. Lippincott.

Bouchard C \& Perusse L (1993) Genetics of Obesity. Annual Review of Nutrition 13, 337-354.

Bray GA \& Campfield LA (1975) Metabolic factors in the control of energy stores. Metabolism 24, 99-117.

Bray GA \& York DA (1979) Hypothalamic and genetic obesity in experimental animals: an autonomic and endocrine hypothesis. Physiological Reviews 59, 719-809.

Campfield LA (1995) Treatment options and the maintenance of weight loss. In Obesity Treatment: Establishing Goals, Improving Outcomes, and Reviewing the Research Agenda, pp. 93-95 [DB Allison and FX Pi-Sunyer, editors]. New York: Plenum Press.

Campfield LA (1996) The role of pharmacological agents in treatment of obesity. In Obesity: Advances in Understanding and Treatment, pp. 4.4.1-4.4.32 [LA Weston and LM Savage, editors]. Southborough, MA: IBC Biomedical Library Series, International Business Communications, Inc.

Campfield LA \& Smith FJ (1990) Systemic factors in the control of food intake: Evidence for patterns as signals. In Handbook of Behavioral Neurobiology. vol. 10, Neurobiology of Food and Fluid Intake, pp. 183-206 [EM Stricker, editor]. New York: Plenum Press.

Campfield LA, Smith FJ \& Burn P (1996a) The OB protein (leptin) pathway - a link between adipose tissue mass and central neural networks. Hormone and Metabolic Research 28, 619-632.

Campfield LA, Smith FJ \& Burn P (1997a) OB protein: a hormonal controller of central neural networks mediating behavioural, 
metabolic and neuroendocrine responses. Endocrinology and Metabolism 4, 81-102.

Campfield LA, Smith FJ, Guisez Y, Devos R \& Burn P (1995) Recombinant mouse OB protein: evidence for a peripheral signal linking adiposity and central neural networks. Science 269 , 546-549.

Campfield LA, Smith FJ, Rosenbaum M \& Hirsch J (1996b) Human eating: Evidence for a physiological basis using a modified paradigm. Neuroscience and Biobehavioral Reviews 20, 133-137.

Campfield LA, Smith FJ, Yu J, Renzetti M, Simko B, Baralt M, Mackie G, Tenenbaum R \& Smith W (1997b) Dietary obesity induces decreased central sensitivity to exogenous $\mathrm{OB}$ protein (leptin) which is reversed by weight loss. Society for Neuroscience Abstracts 23, 815.

Caro JF, Kolaczynski JW, Nyce MR, Ohannesian JP, Opentanova I, Goldman WH, Lynn RB, Zhang P-L, Sinha MK \& Considine RV (1996) Decreased cerebrospinal-fluid/serum leptin ratio in obesity: a possible mechanism for leptin resistance. Lancet 348 , 159-161.

Chadwick DJ \& Cardew G (editors) (1996) In The Origins and Consequences of Obesity, p. 201. Chichester: John Wiley and Sons Ltd.

Chehab F, Lim M \& Lu R (1996) Correction of the sterility defect in homozygous obese female mice by treatment with human recombinant leptin. Nature Genetics 12, 318-320.

Chen H, Charlat O, Tartaglia LA, Woolf EA, Weng X, Ellis SJ, Lakey ND, Culpepper J, Moore KJ, Breitbart RF, Duyk GM, Tepper RI \& Morgenstern JP (1996) Evidence that the diabetes gene encodes the leptin receptor: Identification of a mutation in the leptin receptor gene in $\mathrm{db} / \mathrm{db}$ mice. Cell 84, 491-495.

Chua SC, Chung WK, Wu-Peng XS, Zhang Y, Liu S-M, Tartaglia L \& Leibel RL (1996) Phenotypes of mouse diabetes and rat fatty due to mutations in the OB (leptin) receptor. Science 271, 994-996.

Coleman DL (1973) Effects of parabiosis of obese with diabetes and normal mice. Diabetologia 9, 294-298.

Coleman DL (1978) Obese and diabetes: two mutant genes causing diabetes-obesity syndromes in mice. Diabetologia 14, 141-148.

Coleman DL (1981) Inherited obesity-diabetes syndromes in the mouse. Progress in Clinical and Biological Research 45, $145-158$

Coleman DL \& Hummel KP (1973) The influence of genetic background on the expression of the obese $(o b)$ gene in the mouse. Diabetologia 9, 287-293.

Considine RV, Sinha MK, Heiman ML, Kriauciunas A, Stephens TW, Nyce MR, Ohannesian JP, Marco CC, McKee LJ, Baur TL \& Caro JF (1996) Serum immunoreactive-leptin concentrations in normal-weight and obese humans. New England Journal of Medicine 334, 292-295.

Devos R, Richards JG, Campfield LA, Tartaglia LA, Guisez Y, Van der Heyden J, Travernier J, Plaetinck G \& Burn P (1996) OB protein binds specifically to the choroid plexus of mice and rats. Proceedings of the National Academy of Sciences USA 93, $5668-5673$.

Erickson JC, Clegg KE \& Palmiter RD (1996a) Sensitivity to leptin and susceptibility to seizures of mice lacking neuropeptide $\mathrm{Y}$. Nature 381, 415-418.

Erickson JC, Hollopetter G \& Palmiter RD (1996b) Attenuation of the obesity syndrome of ob/ob mice by the loss of neuropeptide Y. Science 274, 1704-1707.

Ezzell C (1995) Fat times for obesity research: Tons of new information, but how does it all fit together. Journal of the National Institutes of Health Research 7, 39-45.

Ghilardi N, Ziegler S, Wiestner A, Stoffel R, Heim MH \& Skoda RC (1996) Defective STAT signaling by the leptin receptor in diabetic mice. Proceedings of the National Academy of Sciences USA 93, 6231-6235.

Glaum SR, Hara M, Bindokas V, Lee C, Polonsky K, Bell G \& Miller R (1996) Leptin, the obese gene product, rapidily modulates synaptic transmission in the hypothalamus. Molecular Pharmacology 50, 230-235.

Golden PL, Maccagnan TJ \& Pardridge WM (1997) Human bloodbrain barrier leptin receptor. Binding and endocytosis in isolated human brain microvessels. Journal of Clinical Investigation 99, $14-18$.

Hakansson M-L, Brown H, Ghilardi N, Skoda RC \& Meister B (1998) Leptin receptor immunoreactivity in chemically defined target neurons of the hypothalamus. Journal of Neuroscience $\mathbf{1 8}$, 559-572.

Herberg L \& Coleman DL (1977) Laboratory animals exhibiting obesity and diabetes syndromes. Metabolism 26, 59-99.

Hervey GR (1971) Physiological mechanisms for the regulation of energy balance. Proceedings of the Nutrition Society 30, 109-116.

Hervey GR (1988) Physiological factors involved in long-term control of food intake. International Journal of Vitamin and Nutrition Research 58, 477-490.

Hwa JJ, Ghibaudi L, Compton D, Fawzi AB \& Strader CS (1996) Intracerebroventricular injection of leptin increases thermogenesis and mobilises fat metabolism in $o b / o b$ mice. Hormone and Metabolic Research 28, 659-663.

Kaiyala KJ, Woods SC \& Schwartz MW (1995) New model for the regulation of energy balance and adiposity by the central nervous system. American Journal of Clinical Nutrition 62, $1123 \mathrm{~s}-1134 \mathrm{~s}$

Kennedy GC (1953) The role of depot fat in the hypothalamic control of food intake in the rat. Proceedings of the Royal Society of London 140B, 578-592.

Le Magnen J (1992) Neurobiology of Feeding and Nutrition. San Diego, CA: Academic Press.

Lee G, Proenca R, Montez JM, Carrol KM, Darvishzadeh JG, Lee JI \& Friedman JM (1996) Abnormal splicing of the leptin receptor in diabetic mice. Nature 379, 632-635.

Leibel RL, Rosenbaum M \& Hirsch J (1995) Changes in energy expenditure resulting from altered body weight. New England Journal of Medicine 232, 621-628.

Lin L, Truett GE, Levans N \& York DA (1996) Central, but not peripheral administration of leptin reduced the food intake and body weight in Zucker fatty and lean rats. Obesity Research $\mathbf{4}$, $1 \mathrm{~S}$.

Lynn RB, Cao GY, Considine RV, Hyde TM \& Caro JF (1996) Autoradiographic localization of leptin binding in the choroid plexus of ob/ob and db/db mice. Biochemical and Biophysical Research Communications 219, 884-889.

Maffei M, Halaas J, Ravussin E, Pratley RE, Lee GH, Zhang Y, Fei H, Kim S, Lallone R, Ranganathan S, Kern PA \& Friedman JM (1995) Leptin levels in human and rodent: Measurement of plasma leptin and $o b$ mRNA in obese and weight-reduced subjects. Nature Medicine 1, 1155-1161.

Mercer JG, Hoggard N, Williams LM, Lawrence CB, Hannah LT \& Trayhum P (1996) Localization of leptin receptor mRNA and the long form splice variant (Ob-Rb) in mouse hypothalamus and adjacent brain regions by in situ hybridization. FEBS Letters 387 , 113-116.

Montague CT, Farooqi IS, Whitehead JP, Soos MA, Rau H, Wareham NJ, Sewter CP, Digby JE, Mohammed SN, Hurst JA, Cheetham CH, Earley AR, Barnett AH, Prins JB \& O'Rahilly S (1997) Congenital leptin deficiency is associated with severe early-onset obesity in humans. Nature 387, 903-908.

Parameswaran SV, Steffens AB, Hervey GR \& de Ruiter L (1977) Involvement of a humoral factor in regulation of body 
weight in parabiotic rats. American Journal of Physiology 232, R150-R157.

Rohner-Jeanrenaud F, Cusin I, Sainsbury A, Zakrzewska K \& Jeanrenaud B (1996) Neuropeptide Y and leptin in lean and genetically obese fa/fa rats. Hormone and Metabolic Research 28, 642-648.

Rohner-Jeanrenaud F \& Jeanrenaud B (1996) Obesity, leptin, and the brain. New England Journal of Medicine 334, 324-325.

Schwartz MW, Baskin DG, Bukowski TR Kuijper JL, Foster D, Lasser G, Prunkard DE, Porte D Jr, Woods SC, Seeley RJ \& Weigle DS (1996a) Specificity of leptin action on elevated blood glucose levels and hypothalamic neuropeptide $\mathrm{Y}$ gene expression in ob/ob mice. Diabetes 45, 531-535.

Schwartz MW, Figlewicz DP, Baskin DG, Woods SC \& Porte D Jr (1994) Insulin and the central regulation of energy balance: Update 1994. Endocrine Review 2, 109-113.

Schwartz MW, Marks J, Sipols AJ, Baskin DB, Woods SC, Kahn SE \& Porte JD (1991) Central insulin administration reduces neuropeptide $\mathrm{Y}$ mRNA expression in the arcuate nucleus of food-deprived lean $(\mathrm{Fa} / \mathrm{Fa})$ but not obese $(\mathrm{fa} / \mathrm{fa})$ Zucker rats. Endocrinology 128, 2645-2647.

Schwartz MW, Peskind E, Raskind M, Boyko EJ \& Porte D Jr (1996b) Cerebrospinal fluid leptin levels: Relationship to plasma levels and to adiposity in humans. Nature Medicine $\mathbf{2}$, 589-593.

Schwartz MW, Seeley RJ, Campfield LA, Bum P \& Baskin DG (1996c) Identification of targets of leptin action in rat hypothalamus. Journal of Clinical Investigation 98, 1101-1106.

Schwartz MW, Seeley RJ, Woods SC, Weigle DS, Campfield LA, Burn P \& Baskin DG (1997) Leptin increases hypothalamic pro-opiomelanocortin mRNA expression in the rostral arcuate nucleus. Diabetes 46, 2119-2123.

Seeley RJ, van Dijk G, Campfield LA, Smith FJ, Burn P, Nelligan JA, Bell MS, Baskin DG, Woods SC \& Schwartz MW (1996) Intraventricular leptin reduces food intake and body weight of lean rats but not obese Zucker rats. Hormone and Metabolic Research 28, 664-668.

Sinha MK, Opentanova I, Ohannesian JP, Kolaczynski JW, Heiman ML, Hale J, Becker GW, Bowsher RR, Stephens TW \& Caro JF (1996) Evidence of free and bound leptin in human circulation: studies in lean and obese subjects and during short-term fasting. Journal of Clinical Investigation $\mathbf{9 8}$, $1277-1282$.

Smith FJ, Campfield LA, Moschera JA, Bailon P \& Burn P (1996) Feeding inhibition by neuropeptide Y. Nature 382, 307.

Spanswick D, Smith MA, Groppi VE, Logan SD \& Ashford MLJ (1997) Leptin inhibits hypothalamic neurons by activation of ATP-sensitive potassium channels. Nature 390, 521-525.

Stanley BG, Kyrkouli SE, Lampert S \& Leibowitz SF (1986) Neuropeptide Y chronically injected into the hypothalamus: A powerful neurochemical inducer of hyperphagia and obesity Peptides 7, 189-192.

Stephens TW, Basinski M, Bristow PK, Bue-Valleskey JM, Burgett SG, Craft L, Hale J, Hoffmann J, Hsiung HM, Kriauciunas A, MacKeller W, Rosteck PR Jr, Schoner B, Smith D, Tinsley FC, Zhang X-Y \& Heiman M (1995) The role of neuropeptide Y in the antiobesity action of the obese gene product. Nature $\mathbf{3 7 7}$, $530-532$.

Stricker-Krongrad A, Chiesi M, Cumin F, Spanka C, Whitesbread S, Rentsch J, Lollman B, Hofbauer KG \& Levens N (1996) Interactions between leptin and neuropeptide $\mathrm{Y}$ in the control of food intake in the rat. Obesity Research 4,37S.

Tartaglia LA (1997) The leptin receptor. Journal of Biological Chemistry 272, 6093-6096.

Tartaglia LA, Dembski M, Weng X, Deng N, Culpepper J, Devos R, Richards JG, Campfield LA, Clark FT, Deeds J, Muir C, Sanker S, Moriarty A, Moore KJ, Smutko JS, Mays GG, Woolf EA, Monroe CA \& Tepper RI (1995) Identification and expression cloning of a leptin receptor (OB-R). Cell 83, 1263-1271.

Thiele TE, van Dijk G, Campfield LA, Smith FJ, Burn P, Woods SC, Bernstein IL \& Seeley RJ (1997) Central infusion of GLP-1, but not leptin, produces conditioned taste aversion in rats. American Journal of Physiology 272, R726-R730.

Thomas PR (editor) (1995) In Weighing the Options: Criteria for Evaluating Weight-Management Programs. Washington, DC: Food and Nutrition Board, Institute of Medicine, National Academy Press.

van Dijk G, Theile TE, Donahey JCK, Campfield LA, Smith FJ, Burn P, Bernstein IL, Woods SC \& Selley RJ (1996) Central infusion of leptin and GLP-1(7-36) amide differentially stimulate c-FLI in the rat brain. American Journal of Physiology 271 , R1096-R1100.

West DB, York B, Waguespack J, Goudey-Lefevre J \& Price AR (1994) Genetics of dietary obesity in AKR/J $\times S W R / J$ mice: segregation of the trait and identification of a linked locus on chromosome 4. Mammalian Genome 5, 546-552.

White DW \& Tartaglia LA (1997) Leptin and OB-R: body weight regulation by a cytokine receptor. Cytokine and Growth Factors Reviews 7, 303-309.

Yokosuka M, Xu B, Pu S \& Karla SP (1997) The magnocellular part of the paraventricular hypothalamic nucleus (PVN): a selective site for inhibition of NPY-induced food intake by leptin. Society for Neuroscience Abstracts 23, 852 .

Zakrzewska KE, Cusin I, Sainsbury A, Rohner-Jeanrenaud F \& Jeanrenaud B (1997) Glucocorticoids as counterregulatory hormones of leptin: toward an understanding of leptin resistance. Diabetes 46, 717-719.

Zhang Y, Proenca R, Maffei M, Barone M, Leopold L \& Friedman JM (1994) Positional cloning of the mouse obese gene and its human homologue. Nature 372, 425-431. 